ESJ Social Sciences

\title{
The Impact Of Human Capital On Nigeria's Economic Growth
}

\author{
Yusufu Nigel Bachama, PhD, \\ Aisha Adamu Hassan \\ Department of Economics, Gombe State University, Nigeria \\ Bello Ibrahim \\ Department of Economics, Federal University of Kashere, Nigeria
}

\section{Doi:10.19044/esj.2021.v17n15p393}

Submitted: 09 February 2021

Accepted: 12 March 2021

Published: 31 May 2021
Copyright 2021 Author(s)

Under Creative Commons BY-NC-ND

4.0 OPEN ACCESS

Cite As:

Bachama Y.N., Hassan A.A. \& Ibrahim B. (2021). The Impact Of Human Capital On Nigeria's Economic Growth.

European Scientific Journal, ESJ, 17(15), 393. https://doi.org/10.19044/esj.2021.v17n15p393

\section{Abstract}

Despite abundant evidence at microeconomic level, the role of human capital in promoting economic growth and development has not been well documented at the macroeconomic level - specifically in developing countries. This paper seeks to examine the role of human capital on economic growth in Nigeria using time series data covering the period from 1970-2019. The data are sourced from Central Bank of Nigeria (CBN) statistical bulletin and World Development Indicators of the World Bank. The data are analyzed using Autoregressive Distributed Lag model (ARDL). The study reveals that expenditure on health and education are found to be positively and significantly related with economic growth both in the short-run and long-run. However, labor negatively impact on economic growth and it was found to be significant. Again, trade openness and inflation are insignificant in explaining economic growth in this paper. Thus, the paper recommends that, Nigerian government should focus on improving the educational and health sector. Meaning that, huge amount of government budgetary allocation should be directed toward educational and health sector. So also, government should create more jobs opportunities (through skills acquisitions/ vocational training) to minimize the unemployment rate in the country.

Keywords: Human Capital, Labour, Health, Education, Economic Growth 


\section{Introduction}

The role of human capital in the growth process of any nation is very crucial. Every business organizations use three types of capital: physical capital (factory, stocks etc.), financial capital (investments), and intellectual capital (Obeidat 2016; Romele, 2013). Human capital is also seen as a component of intellectual capital. It represents the investments made on humans and encompasses human-related factors like knowledge, skills, experience, sufficiency, business quality, employee relations, emotional intelligence, entrepreneurialism, flexibility, employee loyalty, employee satisfaction, education, and creativity (Adelakun, 2011). Although investment on humans in many businesses is the most difficult investment to control; the role of human capital is still important in examining the growth rate of a country.

In any economic system be it market economy or centrally planned, the major objective is how to increase per capita output and this can be achieved through increase in level of productivity. Per capita output growth is a component of economic welfare. It is revealed from experience that human capital is the most important and promising source of growth in productivity and economic growth besides labor and physical capital. Equipment and technology are products of human minds and can only be made productive by people. The success of any productive program depends on human innovative ideas and creativity (Abramowitz, 1981; Pangeran, 2015; Skapska \& Samul, 2015).

Organization for Economic Co-operation and Development (OECD, 1996), stated that as the global economy shifts towards more knowledge-based sectors (e.g. the manufacture of ICT devices, pharmaceuticals, telecommunications and other ICT-based services, R\&D), skills and human capital development becomes a central issue for policy makers and practitioners engage in economic development both at the national and regional level (OECD,1996). Nonetheless, the impact education and vocational training activities exert upon changing national and regional economies remain less than thoroughly explained and analyzed.

Adelakun (2011) posits that the central focus of every country today (developed or developing) has been finding ways to increase the growth rate of national income and to engage in structural transformation. That is moving away from subsistence and resource-based economy to a production and consumption-based economy in order to break the vicious circle of poverty, low productivity and stagnation. Furthermore, Nigeria is blessed with both natural and human resources. Despite these endowments, the rate of illiteracy is very high in the country as most of the workers are unskilled and they make use of outmoded capital, equipment and methods of production. This by implication reduces their marginal productivity and subsequently leads to low 
real income, low savings, low investment and low rate of capital formation (Jibir \& Abdu, 2017; Bashir, et al., 2014; Odhiambo, Wambugu \& N'anga, 2015).

Meanwhile, the global economy is today divided into two parts comprising of a few rich nations referred to as the developed countries (DCs) and many poor nations called as the less developed countries (LDCs). DCs are characterized by high productivity while the LDCs are characterized by low productivity. According to the level of human capital development and per capita income, Nigeria is classified under the LDCs.

Still ahead, Romer (1990) posits that human capital is a source of economic efficiency. Given that human capital is generally accepted of productivity, human capital could be taken to mean all sorts of knowledge, skills and experiences that improve production capacity, and subsequently results in huge economic growth and development. Organization for Economic Co-operation and Development (OECD), (1996) defines human capital as the contributions of knowledge and skills made by an individual to a country's economy, and thus as the improvement in social and economic development made by an individual.

To sum it up, human capital can be defined as any contributions made by the individuals through their knowledge, skills and experience gained which would lead to the good economic performance of a country. Besides labor and capital, human capital has a significant place in endogenous growth models. Thus, the results of this paper are essential to the Nigerian government to design and implement policies that would enhance human capital development. The remaining parts of the paper are as follows: The review of the literature is presented in section 2. The methodology of the paper is covered in section 3. Data analysis and presentation are reported in Section 4. Finally, the paper is concluded in section 5.

\section{Literature Review}

There are different growth theories in economics that explain economic growth. Among others, these include classical, neo-classical and endogenous growth theories. Considering the basis of economic growth models, it was observed that Smith and Ricardo were the pioneers of classical growth theories. They investigated the growth processes of countries and provided significant contributions to the relevant literature. According to classical theory of economic growth, labor productivity is considered as an exogenous factor which largely depends on the ratio between workforce and physical capital, plus other factors (technical progress), but the important effect of human capital on potential growth of productivity had not been taken into cognizance. As such, new theory of economic growth was developed in the early 1980s to correct the weaknesses of the classical theory by 
emphasizing the importance of education and innovation, (some elements of human capital) in long-term economic growth processes (Jibir \& Abdu, 2016; Pelinescu, 2015).

Neo-classical theorists accepted technology and human capital as exogenous factors which determine long run economic growth (Jibir et al, 2018; Kar \& Ağır, 2006). The endogenous growth models emphasize human capital as a major determinant of long-run economic growth. Romer (1986), was the first to include human capital in the economic growth models. He further, indigenized technology and included human capital into the model, which is contrary to the Neo-classical growth model. In addition, Lucas (1988) adds human capital into the model as the qualification levels of individuals (Ulucak, 2015). Thus, endogenous growth models instead focus on the quality of the population and accept the primary determinants of economic growth as either a direct increase in human capital or indirect activities of human capital like R\&D activities.

The endogenous growth models emphasize human capital as a major determinant of long-run economic development (Romer, 1989; Lucas, 1988). Empirical studies have been carried out by many researchers to examine the nexus between human capital and economic growth in the economic literature. For example, Siddiqui and Rehman (2017) conducted a study to test the between human capital and economic growth in selected nine Asian countries. Their study found that primary and secondary education are more prominent in explaining the fluctuations of economic growth in East Asia, whereas tertiary and vocational training showed positive effects on economic growth in South Asia. The study reveals that government expenditure on education was found to be positively affecting economic growth in both the regions.

Oluwatobi and Ogonrinola (2011) and Jibir and Babayo (2015) investigate the impact of government recurrent and capital expenditure on education and health in Nigeria and their effect on economic growth using secondary source of data. The results show that there is a positive relationship between government recurrent expenditure on human capital development and real output in Nigeria. Ogundari and Awokuse (2018) conduct a study on the impact of human capital on economic growth in Sub-Saharan Africa covering 35 countries from 1980-2008. The study indicates that both expenditure on health and education have a positive effects on economic growth. The contributions of health on economic growth are relatively larger than the impact of education on economic growth. Afridi, Augrah, and Bary (2016) in their study in Pakistan found that human capital is the main driver of economic growth. Ejoro (2020) investigates the causal relationships between government spending on education and economic growth in eight selected Latin American countries. The findings found a positive and significant 
relationship between expenditure on education and economic growth both in the long-run and short-run.

Adelakun (2011) examines the effects of human capital development and economic growth in Nigeria. The study employs the theoretical and Ordinary Least Square method (OLS). The analysis confirms that, there is a strong positive relationship between human capital and economic growth. Muddassar (2019), in his study, investigates the nexus between Human capital and economic growth using a Dynamic Panel Data (DPD) and Generalised Method of Moments (GMM) and provides inferences that human capital positively affects economic growth.

Matousek and Tzeremes (2019) re-examine the effects of human capital on countries economic growth using a sample of 100 countries over the period from 1970t to 2014. The empirical findings suggest that the effects of human capital on countries economic growth levels is positively and significant. Parika and Singh (2020) conduct a study to examine the relationship between human capital and economic growth in India. The study utilizes annual time series data for the period 1980-2017. The major findings of the study suggest that human and physical capital is the major determinants of economic growth.

Jaiyeoba (2015) conducts a study to investigate the nexus between investment in education, health and economic growth in Nigeria using time series data covering the period 1982-2011. Empirical findings reveal that there is a long-run positive relationship between government expenditure on education, health and economic growth in Nigeria. Kanayo (2013) in Nigeria empirically examines the relationship between human capital development and economic growth using time series data. The findings show that investment in human capital in the form of education and capacity building at the primary and secondary levels impact significantly on economic growth. Therefore, it can be clearly observed in the empirical literature above that different studies have been carried out in economics to investigate the relationship between human capital and economic growth within and outside Nigeria. This is because human capital has a significant role in determining economic growth especially in developing countries like Nigeria. In the light of the above, this paper attempts to examine the role of human capital on economic growth in Nigeria in order to add knowledge to the existing literature. The paper focused on the long-run and short-run effects of human capital on economic growth using ARDL model for the period 1970-2019.

\section{Methodology}

Data Sources

In this paper, time series data is used covering the period from 1970 to 2019 and the data was sourced from CBN Statistical Bulletin and World 
Development Indicators of the World Bank. Based on the modern growth theory or endogenous economic growth theory, real gross domestic product (RGDP) is the proxy of economic growth and it is the dependent variable whereas the independent variables are human capital (HC), labor (LB), trade openness (TO), and inflation (INFL). However, expenditure on health and education are used as the proxy of human capital. Labor force is used as the proxy of labor, trade openness is proxied by export plus import as a share of gross domestic product, and inflation is measured by consumer price index.

\section{Model Specification}

Human capital through education and training helps to improve the quality of workforce and improve their aggregate income. Some human capital is related to knowledge and education. Thus, economic growth depends on technological progress and scientific discoveries. It is therefore reasonable to consider economic growth to be a function of human capital. In line with the objective of this paper, the association between human capital and economic growth as done by many studies (Muhammad, Nurdin, Sunusi, \& Che 2012), can be measured by Cobb-Douglas production function. Therefore, the aggregate production function can be stated as follows:

$Y=A K^{\alpha} L^{\beta} H^{\mathrm{C}}$

Where $Y$ is the output, " $A$ " represents technical progress, " $K$ " is the physical capital, " $L$ " is the labour force and " $H$ " denotes human capital which can be replaced by $\mathrm{E}^{\Delta}$ and $\mathrm{E}^{*}$ as government expenditure on education and health respectively. Thus, equation (1) can be re-write as follows:

$Y=A K^{\alpha} L^{\beta} E^{\Delta} E^{*}$.

However, equation (2) can further be written in form of econometrics to include other variables and stochastic term. It is stated below:

$R G D P=E E^{\Delta}+E H^{*}+L B+T O+\varepsilon$

Where:

$$
\begin{gathered}
\text { RGDP = Real gross domestic product } \\
\mathrm{EE}^{\Delta}=\text { Expenditure on education } \\
\mathrm{EH}^{*}=\text { Expenditure on health } \\
\text { LB } \quad \text { = Labor } \\
\mathrm{TO} \quad=\text { Trade openness } \\
\mathrm{IF} \quad=\text { Inflation } \\
\varepsilon \quad=\text { Error term }
\end{gathered}
$$

\section{Tools of Analysis}

Time series research requires stationarity test in order to know the order of integration of the variables included in the model. This helps in avoiding the problem of unit root and also helps in determining the best model to be applied. In view of this, the empirical analysis of this paper consists of 
three major steps. The first step involves the stationarity test, the second step is co-integration test and the third step is the diagnostic tests.

\section{Stationarity Test}

The first step is the stationary test which is very important in any time series research. The stationarity test can be conducted using Augmented Dickey Fuller (ADF) test developed by Dickey and Fuller (1988) and PhilipsPerron test developed by Philips and Perron (1979).

\section{Co-integration Test}

The second step is the autoregressive distributed lag (ARDL) bounds testing approach to co-integration recently developed by Pesaran and Shin (1995). The used of this technique has numerous advantages over other techniques of estimation like Engle and Granger (1987) and Johansen (1991). One of the major advantage of this technique is that it can be applied in respective of the order of co-integration of the independent variables (either I(1) or I(0) or both). More so, ARDL model is statistically a significant tool of econometric analysis and has advantageous over other techniques of analysis because it can accommodate small sample size.

The best model that suits this paper is the autoregressive distributed lag (ARDL) bounds testing approach to co-integration recently developed by Pesaran and Shin (1995). This is because the stationarity test has two combinations (I(1) and $\mathrm{I}(0)$ ). In line with the above, the ARDL approach can be specified as real gross domestic product (RGDP) as a function of lagged value of itself and the current lagged values of the explanatory variables included in the model. In this paper, the first step in ARDL approach is the estimation of conditional ARDL for model one as presented in equation (4):

$$
\begin{aligned}
\Delta \ln R G D P=\beta_{0} & +\beta_{1} \ln R G D P_{t-1}+\beta_{2} \ln E H_{t-1}+\beta_{3} \ln E E_{t-1}+\beta_{4} \ln L B_{t-1}+\beta_{5} T O_{t-1} \\
& +\beta_{6} I N F L_{t-1}+\sum_{i=t}^{n} \theta 1 \Delta \ln R G D P_{t-1}+\sum_{t=1}^{n} \theta 2 \Delta \ln E H_{t-1} \\
& +\sum_{t=1}^{n} \theta 3 \Delta \ln E E_{t-1}+\sum_{t=1}^{n} \theta 4 \ln L B_{t-1}+\sum_{t=1}^{n} \theta 5 T O_{t-1} \\
& +\sum_{t-1}^{n} \theta 6 I N F L_{t-1}+\mu \ldots \ldots \ldots \ldots \ldots \ldots \ldots \ldots \ldots \ldots \ldots \ldots \ldots \ldots \ldots \ldots \ldots \ldots \ldots \ldots \ldots \ldots \ldots \ldots \ldots \ldots \ldots \ldots \ldots \ldots \ldots
\end{aligned}
$$

where $\beta_{0}$ is the constant, $\mu$ is the stochastic error term, $\Delta$ is the first different operator, the parameters $\beta_{0}-\beta_{6}$ denote the long-run parameters, while $\theta_{1}-\theta_{6}$ represents short-run parameters of the model to be estimated through the error correction framework of ARDL. InRGDP is the natural log of real gross domestic product, $\operatorname{lnEH}$ is the natural log of expenditure on education, $\operatorname{lnEE}$ is the natural $\log$ of expenditure on education, $\ln L B$ is the natural $\log$ of 
labor, TO is the trade openness, INFL represents inflation, $\mathrm{n}$ is the optimal lag length and $\beta_{1}-6$ are the coefficients to be estimated in the model.

However, having stated the conditional ARDL model in equation (4) above, the next step is to apply equation (4) in order to test the hypothesis of the paper which states that there is no co-integrating relationship among the variables against the alternative hypothesis that there is long-run relationship between the variables. This is specified as:

$$
\begin{gathered}
\mathrm{H}_{\mathrm{O}}=\beta_{1}=\beta_{2}=\beta_{3}=\beta_{4}=\beta_{5}=0 \\
\mathrm{H}_{1}=\beta_{1} \# \beta_{2} \# \beta_{3} \# \beta_{4} \# \beta_{5} \# 0
\end{gathered}
$$

In addition, the condition for accepting or rejecting the hypothesis states that, the calculated F-statistics is compared with two sets of critical values developed on the ground that the explanatory variables are $\mathrm{I}(\mathrm{d})$ (where $0 \leq \mathrm{d}$ $\leq 1)$. The lower critical values assume that all the variables are I(0) while the upper assumed that they are I(1). The criterion for the F-statistic is, if the calculated F-statistic is greater than upper critical value, then null hypothesis of no long-run relationship is rejected. On the other hand, if the F-statistic is less than lower bound, then the null hypothesis of no co-integration should be accepted. Furthermore, if F-statistic lies within the lower and upper critical bounds, then the result is inconclusive (Pesaran \& Smith, 1997). To obtain the long-run coefficients, equation (5) is specified as:

$$
\begin{aligned}
& \ln R G D P=\beta_{0}+\sum_{i=0}^{p} \beta 1 \ln R G D P_{t-1}+\sum_{i=0}^{p 1} \beta 2 \ln E H_{t-1}+\sum_{i=0}^{p 2} \beta 3 \ln E E_{t-1} \\
& +\sum_{i=0}^{p 3} \beta 4 \ln L B_{t-1}+\sum_{i=0}^{p 4} \beta 5 T O_{t-1}+\sum_{i=0}^{p 5} \beta 6 I N F L_{t-1} \\
& +\mu_{t}
\end{aligned}
$$

Examining the long-run and short-run effects of human capital on economic growth is the core objective of this paper. As such the short-run ARDL model is specified in equation (6) below:

$$
\begin{aligned}
& \Delta \ln R G D P=\beta_{0}+\sum_{i=1}^{P} \beta 1 \ln \Delta R G D P_{t-1}+\sum_{i=1}^{p} \beta 2 \ln \Delta E H_{t-1}+\sum_{i=1}^{p} \beta 3 \ln \Delta E E_{t-1} \\
& +\sum_{i=1}^{p} \beta 4 \ln \Delta L B_{t-1}+\sum_{i=1}^{p} \beta 5 \Delta T O_{t-1}+\sum_{i=1}^{p} \beta 6 \Delta I N F L_{t-1} \\
& +\mu_{t}
\end{aligned}
$$

Looking at the short-run ARDL model, $\beta_{1}-\beta_{6}$ remains unchanged in the model, while $\Delta$ represents coefficients of short-run dynamic to be estimated. 


\section{Results and Discussion}

In this paper, three variables namely: real gross domestic product (RGDP), expenditure on education (EE), trade openness (TO) were found to be I(1) while the remaining variables such as: expenditure on health (HE), labour (LB), and inflation (INFL) are found to be $1(0)$. The combinations of $\mathrm{I}(1)$ and $\mathrm{I}(0)$ lead to the adoption of ARDL.

\section{Unit Root Tests}

The unit root test is conducted using ADF and PP tests. The result of the ADF and PP unit root test is presented in table1. The test is done both with the intercept and trend and intercept at level and first difference. It can be observed from the table 1; at level with intercept inflation (INFL) was stationary. Variables such as, expenditure on health (EH) and labor (LB) are stationary at level both with trend and intercept. While, real gross domestic product (RGDP), expenditure on education (EE), and trade openness (TO) are found to be stationary at first difference with trend and intercept and intercept.

Table 1. ADF Unit Root Test

\begin{tabular}{|c|c|c|c|c|c|}
\hline \multicolumn{3}{|c|}{ At Level } & \multicolumn{3}{c|}{ At First Difference } \\
\hline Variables & Intercept & $\begin{array}{c}\text { Trend \& } \\
\text { Intercept }\end{array}$ & Intercept & $\begin{array}{c}\text { Trend \& } \\
\text { Intercept }\end{array}$ & $\begin{array}{c}\text { Order of } \\
\text { Integration }\end{array}$ \\
\hline RGDP & -0.920 & -2.004 & $-7.684^{* * *}$ & $-7.617^{* * *}$ & $\mathrm{I}(1)$ \\
\hline InEH & -0.447 & $-4.777^{* * *}$ & - & - & $\mathrm{I}(0)$ \\
\hline EE & -1.827 & -2.077 & $-9.558^{* * *}$ & $-9.452^{* * *}$ & $\mathrm{I}(1)$ \\
\hline InLB & -1.487 & $-6.029^{* * *}$ & - & - & $\mathrm{I}(0)$ \\
\hline TO & -2.839 & -2.782 & $-7.885^{* * *}$ & $-7.815^{* *}$ & $\mathrm{I}(1)$ \\
\hline INFL & $-3,442^{* * *}$ & $-4.032^{*}$ & - & - & $\mathrm{I}(0)$ \\
\hline
\end{tabular}

Source: Computed by Author using E-view 10.0.

(a) RGDP, $\operatorname{lnEH}, \mathrm{EE}, \operatorname{lnLB}$, TO, INFL stand for real gross domestic product, log expenditure on health, expenditure on education, log labor, trade openness, and inflation. (b) ***, **, and * denote significance at $1 \%, 5 \%$, and $10 \%$ respectively. I (0) stand s for order of integration at order zero while I(1) stand for order of integration of order one. When PP test is conducted, the result is consistent with the ADF result. Like in the case of ADF, expenditure on health, labor, and inflation are found to be stationary at levels while the remaining variables become stationary after taking their first difference at both constant with trend and intercept. But in PP test result expenditure on health, labor, trade openness, and inflation are found to be stationary at levels while the remaining variables are found to be stationary after taking their first difference as reported in table 2 . 
Table 2. Philips-Perron Stationary Test

\begin{tabular}{|c|c|c|c|c|c|}
\hline \multicolumn{3}{|c|}{ At Level } & \multicolumn{3}{c|}{ At First Difference } \\
\hline Variables & Intercept & $\begin{array}{c}\text { Trend \& } \\
\text { Intercept }\end{array}$ & Intercept & $\begin{array}{c}\text { Trend \& } \\
\text { Intercept }\end{array}$ & $\begin{array}{c}\text { Order of } \\
\text { Integration }\end{array}$ \\
\hline RGDP & -1.334 & -2.301 & $-7.772^{* * *}$ & $-7.848^{* * *}$ & $\mathrm{I}(1)$ \\
\hline InEH & -0.303 & $-4.751^{* * *}$ & - & - & $\mathrm{I}(0)$ \\
\hline EE & -1.469 & -2.574 & $-9.512^{* * *}$ & $-9.414^{* * *}$ & $\mathrm{I}(1)$ \\
\hline InLB & -2.081 & $-6.045^{* * *}$ & - & - & $\mathrm{I}(0)$ \\
\hline TO & $-2.934^{* *}$ & -2.894 & - & - & $\mathrm{I}(0)$ \\
\hline INFL & $-3.274^{* *}$ & -3.268 & -14.569 & -15.346 & $\mathrm{I}(0)$ \\
\hline
\end{tabular}

Source: Computed by Author using E-view 10.0.(a) RGDP, $\operatorname{lnEH}$, EE, lnLB, TO, INFL remained as defined in table 1 above. (b) ***, **, and * denote significance at $1 \%, 5 \%$, and $10 \%$ respectively. I (0) stand s for order of integration at order zero while I(1) stand for order of integration of order one.

It is clearly observed from table 2 above, the PP results reveal that variables such as inflation, labor, trade openness and expenditure on health are in order zero $\mathrm{I}(0)$ while real gross domestic product and expenditure on education were in order one 1(1). Thus, the combination of I(1) and I(0) provides a basis for adopting ARDL approach to co-integration because it can be applied irrespective of order of integration whether ( I(1), I(0) or both) as clearly explained in the methodology section.

\section{Bound Test for Co-integration}

The bound test approach helps in testing the null hypothesis that the coefficient of the lagged levels is zero. However, the F-statistics tests the null hypothesis of no long-run co-integration relationship between the variables. Since the study deploys the time series data it's paramount to decide the optimal lag length of the model. The study determines the optimal lag length of the model by identifying the longest lag and testing until the lags that are significant are found.

Table 3 depicts the results of the computed F-statistics for the model when the real gross domestic product is normalized as the dependent variable - Frgdp (RGDP ,lnEH, EE, lnLB, TO, and INFL) is equal to 5.301 which is higher than the upper critical value at $1 \%, 5 \%$ and $10 \%$ levels of significance. This shows that there is long-run relationship between the variables in the model.

Table 3. Result of bound test for co-integration

\begin{tabular}{|c|c|c|}
\hline \multirow{2}{*}{ Significant level } & \multicolumn{2}{|c|}{ Critical values } \\
\cline { 2 - 3 } & Lower bound & Upper bound \\
\hline 1\% significance level & 3.420 & 3.350 \\
\hline 5\% significance level & 2.620 & 3.790 \\
\hline 10\% significance level & 2.260 & 4.680 \\
\hline F-statistics & 5.301 & $\mathrm{~K}=5$ \\
\hline
\end{tabular}

Source: Computed by Authors using E-view 10.0 
The lag length of each variable is selected using AIC criterion. Critical values are generated under the model with unrestricted intercept and trend. * shows computed statistics falls above the upper and lower bound values at $1 \%$, $5 \%$, and $10 \%$ level of significance respectively.

\section{Short and Long Run Relationship}

Since the growth model is found co-integrated, the long run and shortrun parameters of the ARDL model are estimated and the results are presented in Table 4.

Table 4. Estimated long-run and short-run coefficient using ARDL approach

\begin{tabular}{|c|c|c|c|c|c|}
\hline \multicolumn{3}{|c|}{ Long-run Model $\{1,1,1,2,0,2\}$} & \multicolumn{3}{c|}{ Short-run Model $\{1,1,1,2,0,2\}$} \\
\hline \multicolumn{2}{|c|}{ Dependent variable: InRGDP } & \multicolumn{2}{|c|}{ Dependent variable: InRGDP } \\
\hline Regressor & Co-efficient & P.value & Regressor & Co-efficient & P.value \\
\hline InEH & $0.125^{* *}$ & 0.035 & $\Delta$ InEH & 0.001 & 0.980 \\
\hline InEE & $0.446^{* * *}$ & 0.000 & $\Delta$ InEE & $0.082^{*}$ & 0.057 \\
\hline LnLB & $-1.280^{* *}$ & 0.047 & $\Delta$ LnLB & -0.025 & 0.846 \\
\hline TOP & 0.003 & 0.180 & $\Delta$ TOP & 0.002 & 0.591 \\
\hline INFL & -0.003 & 0.297 & $\Delta$ INFL & 0.001 & 0.471 \\
\hline C & $12.566^{* *}$ & 0.008 & ECM(-1) & $-0.396^{* * *}$ & 0.001 \\
\hline
\end{tabular}

Notes: (a) InEH, InEE, InLB, InRGDP indicates log of expenditure on health, log of expendiyure on education, log of labour and log of real gross domestic product while variables TOP, INFL, C and ECM denote trade openness, inflation, constant and error correction term respectively. (b). *, **, and *** is the level of significance at $10 \%, 5 \%$ and $1 \%$. (c). However, the optimal lag length is determined by Akaike Information Criterion.

Source: Authors' computation using E-views 10.0.

Table 4 above reports two models estimated both in the short-run and long-run. It be can be seen in the table, the long-run and short-run estimated equations indicates that, expenditure on education is positively related with real gross domestic product both in the short-run and long-run but happened to be significant in the long-run at $5 \%$ level of significance. According to the coefficient value of $\operatorname{lnEH}$ (i.e government expenditure on health), a $1 \%$ increase in government spending on health may likely leads to $0.13 \%$ increase in real gross domestic product in Nigeria. This result supports the endogenous growth model which argues that, the growth of an economy is largely depends on the labor and human capital. In addition, Nigeria is one of the developing countries where there are prevalence of many this may affect the lives of many people and thus limit their productivity which in turn may bring about decline in the growth of an economy. If government spends huge amount of money in the health sector as found in this paper, it is expected this would help to improve health status and increase their level of productivity.

The variable expenditure on education is found to be positive and significant with real gross domestic product in the long-run and short-run at $5 \%$ and $10 \%$ respectively. The coefficient of $\operatorname{lnEE}$ (expenditure on education) 
shows that $1 \%$ increase in government expenditure on education brings about $0.45 \%$ and $0.08 \%$ increase in the real gross domestic product in the long-run and short-run respectively. More so, expenditure on education is very important in an economy because it helps in research and innovations increased the number of skilled workers through learning and training etc. Studies have found that many advanced countries have their development through improvement in human capital (Muddasar, 2019; \& Ulukak, 2015). This positives nexus between expenditure on health and real gross domestic product is in line with the modern growth model which believed that, human capital determined economic growth of the country.

The coefficient of labor is found to be significant only in the long-run but the sign of the relationship is negative both in the long run and short run with real gross domestic product. This negative relationship implies that a $1 \%$ unit increase in labor reduces RGDP by $1.28 \%$ in the long-run. This negative impact of labor on RGDP may be connected with the massive rate of unemployment in Nigeria. The empirical result of the relationship between labor and real gross domestic product is against the theoretical justification of the endogenous theory who believed that, the growth of an economy in the long-run is determined by the human capital and labour.

Although, the relationship between trade openness and real gross domestic product are found to be positive which have met a prior expectations but was insignificant both in the short-run and long-run. So also, inflation is the model estimated is found insignificant but negatively affect real gross domestic product in the long-run but positively related in the short-run. The ECM(-1) values simply shows the speed of adjustment whenever there is disequilibrium in the model. Based on the result obtained above, the speed at which disequilibrium will restore back to equilibrium is by $39 \%$.

\section{Diagnostic Analysis of Data}

In time series research, the reliability and acceptability of the results after model has been estimated is the ability of the model to pass all the necessary diagnostic tests especially those that may lead to spurious results. The study conducted robust diagnostic tests for autocorrelation, heteroscedasticity, normality, stability and specification tests which are presented in table 4.

Table 5. Model Diagnostic Tests

\begin{tabular}{|c|c|c|}
\hline Diagnostics test techniques & Statistics & Probabilities \\
\hline Breusch-Godfrey Serial correlation LM test & 0.369 & 0.694 \\
\hline Heteroscedasticity test & 1.711 & 0.107 \\
\hline Normally test & 0.675 & 0.564 \\
\hline Ramsey RESET test & 1.044 & 0.314 \\
\hline
\end{tabular}

Source: Computed by author using E-views 10.0. 
Table 5 depicts diagnostics tests conducted for the growth model. One of the vital assumptions of ARDL bounds test is that the error term should not have autocorrelation. İn this paper, Breusch-Godfrey LM serial correlation test is conducted and the result indicates that null hypothesis cannot be rejected as the F-statistic for test is found to be 0.369 with probability value of 0.694 indicating that there is absence of serial correlation in the model.

Furthermore, the diagnostic tests also reveal that the model is normally distributed. In the same vein, the model passes the tests for heteroscedasticity and linearity. The study also tested for model misspecification using Ramsey RESSET test and the result reveals that the null hypothesis cannot be rejected indicating that the growth model is correctly specified.

\section{Conclusions and Policy Recommendations}

The relationship between human capital and economic growth has been carried out in the field of economics by many researchers yielding different outcomes. This paper attempts to examine the effects of human capital on economic growth using expenditure on education and health as the proxies of human capital. The results show that, three variables namely: expenditure on health and expenditure on education are found to be positively and significantly associated with real domestic product. While labor is found to be significant but negatively impacts on real gross domestic product. The remaining independent variables; inflation and trade openness were insignificant in determining the level of economic growth in Nigeria both in the short-run and long-run. Thus, the paper recommends that, Nigerian government should focus on improving the educational and health sector. Meaning that, huge amount of government budgetary allocation should be directed toward educational and health sectors. So also, government should create more jobs opportunities (through skills acquisitions/ vocational training) to minimize the unemployment rate in the country. This helps to increase per capita income and increase spending by the populace. The findings of this paper is in line with the studies done by; Adelakun, (2011), Oluwatubi and Ogonrinola (2011), Jibir and Abdu (2020), Kanayo, (2013), Ajaiyeobi, (2015), Ogundari and Awokuse (2018), Affandi, (2019) and Parika and Singh (2020).

\section{References:}

1. Abramowitz M. (1981): Welfare quandaries and productivity concerns. The American Economic Review, 7, 1-17.

2. Adamu, J., \& Hajara, A. I. B. (2015). FDI and Economic Growth Nexus: Empirical Evidence from Nigeria (1970-2012). Journal of Economics and Sustainable Development, 8(1), 43-56. 
3. Adelakun, O. J. (2011). Human capital development and economic growth in Nigeria. European Journal of Business and Management, 3(9), 29-38.

4. Afridi, A. H. (2016). Human capital and economic growth of Pakistan. Business \& Economic Review, 8(1), 77-86.

5. Bashir, T., Mansha, A., Zulfiqar, R., \& Riaz, R. (2014). Impact of FDI on economy growth: a comparison of South Asian States \& China. European Scientific Journal, 10(1).

6. Dickey, D. A., \& Fuller, W. A. (1979). Distribution of the estimators for autoregressive time series with a unit root. Journal of the American statistical association, 74(366a), 427-431.

7. Engle, R. and Granger, W. J. (1987), "Co-integration and Error Correction: Representations, Estimations and Testing”, Econometrics, 55(2), 251-276.

8. Jaiyeoba, S.V. (2015), Human capital investment and economic growth in Nigeria. African Journal Online (AJOL), 9(1).

9. Jibir, A., \& Abdu, M. (2017). Foreign Direct Investment-Growth Nexus: The Case of Nigeria. European Scientific Journal, 13(1), 2355.

10. Jibir, A., \& Musa, A. (2016). Causal links between foreign capital inflows and economic growth: Empirical evidence from Nigeria. International Journal of Accounting \& Business Finance, 2(1), 45-56.

11. Jibir, A., Abdu, M. (2020). Human Capital and Propensity to Protect Intellectual Properties as Innovation Output: the Case of Nigerian Manufacturing and Service Firms. J Knowl Econ. https://doi.org/10.1007/s13132-020-00657-x

12. Jibir, A., Abdullahi, S., Abdu, M., Buba, A., \& Ibrahim, B. (2018). External debt-growth nexus in Nigeria revisited. Asian Economic and Financial Review, 8(1), 117-130.

13. Jibir, A., Bappayaya, B., \& Babayo, H. (2015). Re-examination of the impact of unemployment on economic growth of Nigeria: An econometric approach. Journal of Economics and Sustainable Development, 6(8), 116-123.

14. Kanayo, O. (2013). The impact of human capital formation on economic growth in Nigeria. Journal of Economics, 4(2), 121-132.

15. Kar, A \& Agir, P (2015) Investment in human capital. The American Economic Review, 51(1), 1-16.

16. Kazmi, S. M., Ali, K., \& Ali, G. (2017). Impact of human capital on economic growth: Evidence from Pakistan.

17. Lucas S.R. (1988); 'The mechanics of economic development' journal of monetary economics.pp30-42. 
18. Lucas, R. (1988). On the mechanics of economic development. Journal of monetary Economics. 3,23-45.

19. Matousek, R., \& Tzeremes, N. G. (2019). The asymmetric impact of human capital on economic growth. Empirical Economics, 1-26.

20. Mohammad J., \& nurdin, M, che, Y. (2012). The role of human capital in economic development evidence from aggregate cross-country data. Journal of Monetary Economics, 34, 143- 173.

21. Mudassaar, K. (2019). Human capital and economic growth nexus: Does corruption matter?. Pakistan Journal of Commerce and Social Sciences (PJCSS), 13(2), 409-418.

22. Obeidat, Z. M. (2016). Human Capital Investment And Training In Islamic Banking Industry In Jordan. Jordan Islamic Bank for Finance and Investment. European Scientific Journal, 12(10).

23. Odhiambo, S. A., Wambugu, A., \& Ng'ang'a, T. K. (2015). Has Quality of Governance Affected the Effectiveness of Health Expenditure on Adult Health in Sub-Saharan Africa?.

24. OECD - Organisation for Economic Cooperation and Development. The knowledge-based economy. Paris: OECD, 1996.

25. Ogundari, K., \& Awokuse, T. (2018). Human capital contribution to economic growth in Sub-Saharan Africa: does health status matter more than education?. Economic Analysis and Policy, 58, 131-140.

26. Oluwatobi, S. A., \& Ogunrinola, I. O. (2011). Government expenditure on human capital development: Implications for economic growth in Nigeria. Journal of sustainable development, 4(3).

27. Pangeran, P. (2015). Entrepreneurs' social and human capital on their knowledge of finance alternatives:evidence from Indonesia. European Scientific Journal, 11(10).

28. Parika, A., \& Singh, B. P. (2020). How Does Human Capital Affect Economic Growth in India? An Empirical Analysis.

29. Pelinescu, E. (2015). The impact of human capital on economic growth. Procedia Economics and Finance, 22(1), 184-190.

30. Pesaran, M.H. and Shin, Y. (1995), Long Run Structural Modelling, No. 9419, Faculty of Economics, University of Cambridge: UK.

31. Pesaran, M.H. and Smith, R. (1997), "Estimating Long-Run Relationships From Dynamic Heterogenous Panels, Journal of Econometrics, 68(1), 79-113.

32. Romele, L. (2013). Human capital development and economic growth in Latvia. European Scientific Journal, 9(31).

33. Romer, P, (1990). Human capital and growth: theory and evidence, Carnegie Rochester Conference Series on Public Policy 32, 251-286;

34. Romer, P. M. (1990). Endogenous Technological Change.journal of political economy, 8(5) 
35. Siddiqui, A., \& Rehman, A. U. (2017). The human capital and economic growth nexus: in East and South Asia. Applied Economics, 49(28), 2697-2710.

36. Skapska, E., \& Samul, J. (2015). Human capital indicators in service industries: from workforce profile to output measures. European Scientific Journal, 11(10).

37. Ulucak, R. (2015). The environment in economic growth models: An application based on ecological footprint (Unpublished doctoral thesis, Erciyes University, Social Sciences Institute) (in Turkish). 